\title{
Molecular Compositions and Sources of Organic Aerosols from Urban Atmosphere in the North China Plain during the Wintertime of 2017
}

\author{
Xiaodi Liu ${ }^{1}$, Jingjing Meng, ${ }^{1, *}$, Zhanfang Hou ${ }^{1,2}$, Li Yan ${ }^{3}$, Gehui Wang,4, Yanan Yi ${ }^{1}$, \\ Benjie Wei ${ }^{1}$, Mengxuan Fu ${ }^{1}$, Jianjun $\mathrm{Li}^{2}$, Junji Cao ${ }^{2}$ \\ ${ }^{I}$ School of Environment and Planning, Liaocheng University, Liaocheng 252000, China \\ 2 State Key Laboratory of Loess and Quaternary Geology, Key Lab of Aerosol Chemistry and Physics, Institute of Earth \\ Environment, Chinese Academy of Sciences, Xi'an 710075, China \\ ${ }^{3}$ Chinese Academy for Environmental Planing, Beijing 100012, China \\ ${ }^{4}$ Key Laboratory of Geographic Information Science of the Ministry of Education, School of Geographic Sciences, East \\ China Normal University, Shanghai 200062, China
}

\begin{abstract}
$\mathrm{PM}_{2.5}$ samples were collected from Liaocheng, a typical city in the North China Plain, during a winter haze episode around 2017 Chinese Spring Festival (Lunar New Year, LNY) to investigate the impact of firework on organic aerosols. A comparison of $\mathrm{PM}_{2.5}$ concentrations during different periods, with different air mass origins, and under different pollution situations was done. Organic compounds including normal alkanes ( $n$-alkanes), polycylic aromatic hydrocarbons (PAHs), saccharides, and organic acids in $\mathrm{PM}_{2.5}$ aerosols were determined by GC/MS. Sources were analyzed by diagnostics ratios and principal component analysis/multiple linear regression (PCA/MLR) model. The results showed that fireworks burning has significant impacts on fine particle pollution. During the haze period, a sharp increase in $n$-alkanes, PAHs, saccharides, and fatty acids were observed, but the influence of fireworks burning on $n$-alkanes concentration is minor. The concentrations of carcinogenic PAHs during haze and LNY periods were more than three times higher than those in the clean period, indicating that PAHs were more carcinogenic during the two periods. In addition, the estimated ILCR for children and adults were both about three times higher than those in the clean periods, suggesting a moderate potential carcinogenic risk in Liaocheng. The higher concentration and the dominance of levoglucoan in the total saccharides suggested that the biomass burning is the predominance source of saccharides. Both the ratios of $\mathrm{C}_{18: 1} / \mathrm{C}_{18: 0}$ and $\mathrm{BaP} / \mathrm{BeP}$ were the highest during the haze period, indicating that aerosols in the haze period were more oxidized. According to the source precise molecular tracers and the PCA-MLR model, coal combustion, biomass burning, and vehicle emissions were the major sources of organic compounds in $\mathrm{PM}_{2.5}$ aerosols during the winter in Liaocheng, cooking activity and firework burning had impact on organic aerosols obviously during LNY. Our data provided first analysis of the molecular distributions and sources of organic aerosols during Chinese Spring Festival in Liaocheng and their potential effects on human health.
\end{abstract}

Keywords: Organic compounds; $\mathrm{PM}_{2.5}$; Fireworks burning; Source identification; Health risk.

\section{INTRODUCTION}

In recent decades, haze frequently occurred in China because of rapid urbanization and industrialization without an efficient emission control (Huang et al., 2014; Wu et al., 2018; Zhao et al., 2018). Previous studies have demonstrated that both unfavorable diffusion conditions and anthropogenic sources emissions play key roles in the formation of haze pollution (Chen et al., 2017; Wang et al., 2017). Haze events have gained considerable attention because of its significant

\footnotetext{
${ }^{*}$ Corresponding author.

E-mail address: mengjingjing@1cu.edu.cn
}

impact on visibility, air quality, human health, and globle climate change (Kanakidou et al., 2004; Wang et al., 2016; Wang et al., 2018). Recent studies have demonstrated that organic constituents are major pollutants causing haze pollution events, especially the seconday organic compounds (Huang et al., 2014; Ren et al., 2018). Organic aerosol (OA) accounts for a substantial fraction (20-90\%) of the global submicron aerosol loading (Kroll and Seinfeld, 2008; Hallquist et al., 2009). Asubstantial fraction (up to 80\%) of OA is water-soluble (Verma et al., 2017), and thus it has a crucial impact on radiative forcing of aerosols by altering the cloud condensation nuclei (CCN) (Zhang et al., 2015; Wang et al., 2016; Meng et al., 2018). Moreover, a large quantity of OA (e.g., polycyclic aromatic hydrocarbons (PAHs), polychlorinated biphenyls (PCBs), and $n$-alkanes) 
is cytotoxic, mutagenic, and carcinogenic for humans (Zhang et al., 2009; Yang et al., 2017a; Huang et al., 2018), resulting in an increasing concern about its source, formation mechanism, and emission control (Kong et al., 2015a, b; Nirmalkar et al., 2015a; Zhao et al., 2018).

OA can be either directly emitted from vehicle exhaust, biomass burning, fossil fuel combustion, and industrial processes or indirectly derived from photochemical oxidation of organic precursors in urban atmosphere (Rogge et al., 1993a, b; Li et al., 2009; Fu et al., 2016; Singh et al., 2017). Previous studies showed that the severe haze pollution event was driven, to a large extent, by secondary aerosol formation, which contributed 44-71\% of organic aerosol (Huang et al., 2014). Wang et al. (2016) found that, among the main nonrefractory $\mathrm{PM}_{2.5}$ species in Xi'an, organic matter, nitrate, and sulfate were most abundant throughout a pollution episode. Furthermore, the enhanced sulfate formation during the hazy periods was also accompanied by simultaneously increased formation of organic matter. Some studies also found sharp increases in OC during firework burning periods (Feng et al., 2012; Jung et al., 2018). Typically in China, firecracker displays are a traditional way to celebrate Chinese New Year, which can cause severe haze episodes in surrounding areas (Jiang et al., 2015). Han et al. (2014) suggested that the influence of fireworks on air quality lasts for more than $15 \mathrm{hr}$ and estimated that the amount of $\mathrm{PM}_{2.5}$ produced from fireworks in Wuhan in February 2013 was more than 39.57 tons. Thus far, most surveys of fireworks displays have focused on the determination of the concentration of inorganic components and metals (Wang et al., 2007b; Li et al., 2013b), very limited information has been provided on the characteristics of organic compounds during the Chinese Spring Festival (Li et al., 2009; Kong et al., 2015a). Therefore, more data are needed to understand the influence of fireworks burning on $\mathrm{PM}_{2.5}$.

In this study, $\mathrm{PM}_{2.5}$ and its chemical species including $n$-alkanes, PAHs, saccharides, and fatty acids were concurrently measured on a 12-hour basis in Liaocheng city to explore the pollution characteristics, sources of organic compounds in $\mathrm{PM}_{2.5}$ as well as human health risk level during haze and fireworks buring periods. In January 2017, an extremely severe haze occurred in eastern and central China with a record daily $\mathrm{PM}_{2.5}$ concentration of over $450 \mu \mathrm{g} \mathrm{m}^{-3}$ observed in Beijing, the largest city in the North China Plain, attracting worldwide attention. Liaocheng is an inland city located in the center of the North China Plain, one of the regions with the worst air pollution in the world (Meng et al., 2018), which suffering from serious air pollution and was listed as Jing-Jin-Ji air pollution transmission channel city ("Air pollution prevention and control plan for Jing-JinJi and surrounding areas in 2017"). To our knowledge, this is the first time to fill the knowledge gap in the compositions and sources of organic aerosols in Liaocheng, which in turn may inform policy for local and regional pollution control strategies in the North China Plain.

\section{MATERIALS and METHODS}

\section{Sample Collection}

As a Jing-Jin-Ji air pollution transmission channel city, Liaocheng is located in the southwestern part of Shandong province in the North China Plain. $\mathrm{PM}_{2.5}$ samples were collected on the rooftop of a four-story building (12 $\mathrm{m}$ above the ground) on the campus of Liaocheng University, which is located in the southeast of Liaocheng city $\left(36.44^{\circ} \mathrm{N}, 116.02^{\circ} \mathrm{E}\right)$ (Fig. 1). The sampling site represents a typical urban setting influenced by traffic, residential, and commercial pollution in Liaocheng city. $\mathrm{PM}_{2.5}$ samples were collected on a day/night basis using a mid-volume sampler (KC-120H, Qingdao Laoshan Company, China) at an airflow rate of $100 \mathrm{~L} \mathrm{~min}^{-1}$ from January 17 to February 7 of 2017. The daytime samples were collected from 8:00 AM to 19:50 PM, while nighttime samples were collected from 20:00 PM to 7:50 AM of the next day. Field blanks were collected before, during, and after the sampling campaign by putting pre-combusted filters onto the sampler for $10 \mathrm{~min}$ without pumping. The sampling period covers the Chinese Lunar New Year (LNY) festival on January 28.
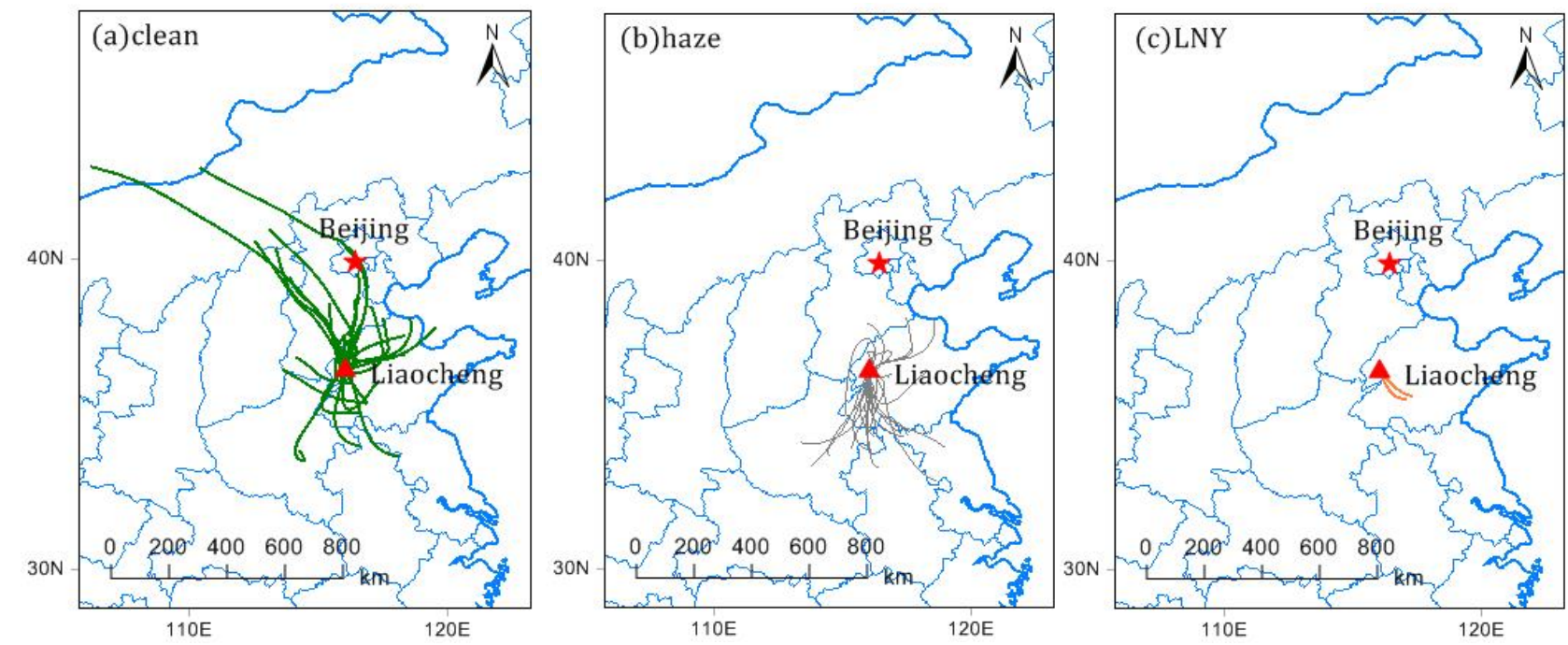

Fig. 1. Backward trajectories of air masses during the sampling periods. 
The meteorological parameters during sampling period are shown in Fig. 2. Wind speed varied from 0.5 to $2.5 \mathrm{~m} \mathrm{~s}^{-1}$, and winds mostly came from the south. Temperature ranged from $-4.2^{\circ} \mathrm{C}$ to $8.6^{\circ} \mathrm{C}$ with an average of $1.9^{\circ} \mathrm{C}$. Relative humidity covered a range of $20.5-75.1 \%$ with an average of $46.1 \%$. It is generally sunny and occasionally cloudy throughout the entire sampling period.

\section{Sample Analyses}

Detailed methods for extraction, derivatization, and gas chromatography/mass spectrometry (GC/MS) analysis were described in previous studies (Wang and Kawamura, 2005). Briefly, one fourth of the sample/blank filter was cut into pieces and extracted with a mixture of dichloromethane and methanol $(2: 1, \mathrm{v} / \mathrm{v})$ under ultrasonication $(15 \mathrm{~min}$, three times). The solvent extracts were filtered through quartz wool packed in a Pasteur pipette, concentrated using a rotary evaporator under a vacuum condition, and then dried using pure nitrogen. After reactiing with $60 \mu \mathrm{L}$ mixture of N,O-bis-(trimethylsilyl) trifluoroacetamide (BSTFA) and pyridine $(5: 1, \mathrm{v} / \mathrm{v})$ at $70^{\circ} \mathrm{C}$ for $3 \mathrm{hr}$, the derivatives were diluted with $140 \mu \mathrm{L}$ of $n$-hexane containing $\mathrm{C}_{13} n$-alkane as an internal standard prior to GC/MS determination.

GC/MS analysis of the derivatized fraction was performed using a Hewlett-Packard 6890 GC coupled to a Hewlett-Packard 5973 MSD. The GC separation was carried out on a DB-5MS fused silica capillary column in the $\mathrm{GC}$ oven at temperature programmed from $50^{\circ} \mathrm{C}(2 \mathrm{~min})$ to $120^{\circ} \mathrm{C}$ at $15^{\circ} \mathrm{C} \mathrm{min}^{-1}$ and then to $300^{\circ} \mathrm{C}$ at $5^{\circ} \mathrm{C} \mathrm{min}{ }^{-1}$ with a final isothermal holds at $300^{\circ} \mathrm{C}$ for $16 \mathrm{~min}$. The sample was injected in a splitless mode at an injector temperature of $280^{\circ} \mathrm{C}$ and then scanned from 50 to 650 Da using electron impact (EI) mode at $70 \mathrm{eV}$. Method detection limits (MDLs) for major compounds, that is, nonacosane $\left(\mathrm{C}_{29}\right.$ alkane), benzo(b)fluoranthene (BbF), levoglucosan (Levo), hexadecanoic $(\mathrm{C} 16: 0)$ and tere-phthalic acid $(\mathrm{t}-\mathrm{Ph})$ were $0.16,0.02,0.11,0.70$ and $0.02 \mathrm{ng} \mathrm{m}^{-3}$, respectively.

\section{Data Analysis}

The meteorological data of Liaocheng, including ambient temperature, relative humidity, wind speed and visibility, were obtained from the Liaocheng Meteorological Bureau (http://hbj.liaocheng.gov.cn/) and shown in Fig. 2. In this study, the haze period was defined as the period with 1-hr $\mathrm{PM}_{2.5}$ concentration higher than $75 \mu \mathrm{g} \mathrm{m}^{-3}$, which is the secondary grade number of 24-hr average value of China National Ambient Air Quality Standard (CNAAQS). The remaining periods except for the LNY were defined as the clean period.

To understand the impact of firework burning on $\mathrm{PM}_{2.5}$, element levels between LNY and before, after LNY can be compared by Eqs. (1) and (2) (Wu et al., 2014; Feng et al., 2016):

$$
\begin{gathered}
R_{L p}=\frac{C_{e i}^{L} / C_{\mathrm{PM} 2.5}^{L}}{C_{e i}^{p} / C_{\mathrm{PM} 2.5}^{p}} \\
R_{L a}=\frac{C_{e i}^{L} / C_{\mathrm{PM} 2.5}^{L}}{C_{e i}^{a} / C_{\mathrm{PM} 2.5}^{a}}
\end{gathered}
$$

where $R_{L p}$ is the relative enrichment of certain element between $\mathrm{CNY}$ and pre-CNY, $\mathrm{R}_{\mathrm{La}}$ is the relative enrichment of certain element between $\mathrm{CNY}$ and pre-CNY. $C_{e i}^{L}$ is the concentration of given element in LNY, while $C_{e i}^{p}$ and $C_{e i}^{a}$ are the concentrations of the corresponding element before and after LNY. $C_{\mathrm{PM} 2.5}^{L}, C_{\mathrm{PM} 2.5}^{p}$, and $C_{\mathrm{PM} 2.5}^{a}$ are the $\mathrm{PM}_{2.5}$ concentrations in LNY before and after LNY, respectively.

The 48-hr backward trajectories of air masses were calculated using the HYSPLIT model (Hybrid Single Particle Langrangian Integrated Trajectory Model) (http://ready.arl. noaa.gov/HYSPLIT_traj.php). These trajectories were calculated two times per day (08:00 and 20:00) with the arrival level at $500 \mathrm{~m}$. The analysis of the trajectories was based on the GIS-based software TrajStat (Xie et al., 2009).

\section{Quality Assurance and Quality Control (QA/QC)}

All the samples were collected onto the prebaked $\left(450^{\circ} \mathrm{C}\right.$, $8 \mathrm{hr}$ ) quartz filters and all pre-baked glasswares were rinsed with methanol, dichloromethane, and hexane immediately before using to avoid any potential contamination. After sampling, each filter was sealed in an aluminum foil bag and stored in a freezer $\left(-20^{\circ} \mathrm{C}\right)$ to avoid the evaporation of volatile components prior to analysis. The derivatived sample was injected in a splitless mode at an injector temperature of $280^{\circ} \mathrm{C}$ and scanned with an electronic impact (EI) mode at $70 \mathrm{eV}$. GC/MS response factors were determined using the authentic standards (Wang et al., 2006). The average recovery of the 70 compounds including $n$-alkanes, PAHs, saccharides, fatty acids, and aromatic acids was higher than $80 \%$. The target compounds in the field blank samples were lower than $4 \%$ of those in the ambient samples.

\section{RESULTS AND DISCUSSION}

\section{Mass Concentration of PM 2.5}

The temporal variations of $\mathrm{PM}_{2.5}$ mass concentration during the sampling campaign were shown in Fig. 2 along with the meteorological parameters. The average concentration of $\mathrm{PM}_{2.5}$ were $130 \pm 70 \mu \mathrm{g} \mathrm{m}^{-3}$ during the sampling period (Table 1), which were higher than those measured during the same periods in Beijing $\left(88.7 \mu \mathrm{g} \mathrm{m}^{-3}\right)$, Tianjin $\left(89.0 \mu \mathrm{g} \mathrm{m}^{-3}\right)$, Jinan $\left(97.1 \mu \mathrm{g} \mathrm{m}^{-3}\right)$, and Zhengzhou $\left(93.1 \mu \mathrm{g} \mathrm{m}^{-3}\right)($ China air quality online monitoring and analysis platform, http://www.aqistudy.cn), indicating that Liaocheng was suffering from serious air pollution. There were no significant differences between the $\mathrm{PM}_{2.5}$ concentrations in the day and night during the sampling periods $(p>0.05)$. The mean concentration of $\mathrm{PM}_{2.5}$ was highest in LNY $\left(174 \pm 49 \mu \mathrm{g} \mathrm{m}^{-3}\right)$, followed by haze period $\left(162 \pm 66 \mu \mathrm{g} \mathrm{m}^{-3}\right)$, which were about 2.6 and 2.4 times higher than those during clean period $\left(67 \pm 11 \mu \mathrm{g} \mathrm{m}^{-3}\right)$, respectively. $\mathrm{PM}_{2.5}$ concentration in LNY's Eve was 1.8 times higher than that during the daytime of the LNY (no fireworks) (Fig. 2(d)), suggesting that fireworks burning has significant impacts on fine particle pollution. As shown in Fig. 1(c), the backward trajectories during LNY were transported for short distances, which 


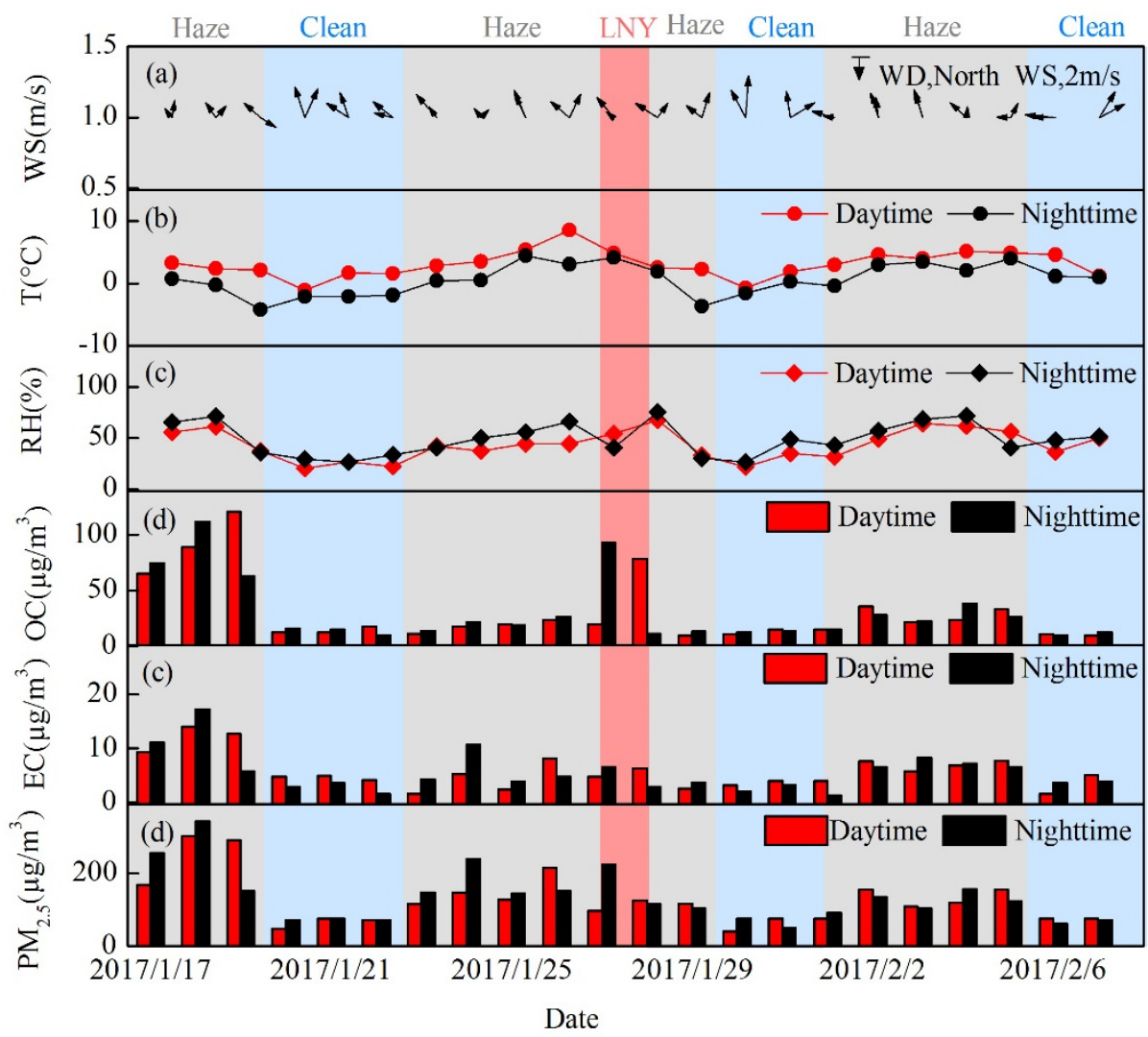

Fig. 2. Temporal variations of $\mathrm{PM}_{2.5}, \mathrm{OC}, \mathrm{EC}$, and meteorological parameters during the sampling period: (a) wind direction (WD) and wind speed (WS), (b) temperature (T), (c) relative humidity (RH), (d) mass concentration of OC, (e) mass concentration of EC, and (f) mass concentration of $\mathrm{PM}_{2.5}$.

Table 1. Mass concentration (ng $\mathrm{m}^{-3}$ ) of $\mathrm{PM}_{2.5}$ and organic compounds of samples collected in Liaocheng City during the winter of 2017.

\begin{tabular}{|c|c|c|c|c|c|c|}
\hline & \multicolumn{2}{|c|}{ Clean period } & \multicolumn{2}{|c|}{ Haze period } & \multicolumn{2}{|c|}{ LNY period } \\
\hline & Mean \pm SD & Range & Mean \pm SD & Range & Mean \pm SD & Range \\
\hline $\mathrm{PM}_{2.5}$ & $67 \pm 11$ & $41-76$ & $162 \pm 66$ & $90-342$ & $174 \pm 49$ & $125-223$ \\
\hline$n$-Alkanes & $363 \pm 116$ & $219-706$ & $536 \pm 263$ & $179-1251$ & $391 \pm 77$ & $313-469$ \\
\hline Plant wax $n$-alkanes & $42 \pm 20$ & $14-101$ & $71 \pm 40$ & $12-179$ & $46 \pm 20$ & $26-67$ \\
\hline Fossil fuel $n$-alkanes & $320 \pm 21$ & $278-365$ & $465 \pm 29$ & $303-474$ & $344 \pm 21$ & $323-364$ \\
\hline CPI & $1.2 \pm 0.1$ & $1.0-1.5$ & $1.2 \pm 0.2$ & $0.9-1.8$ & $1.1 \pm 0.1$ & $1.0-1.2$ \\
\hline PAHs & $37 \pm 19$ & $12-78$ & $54 \pm 27$ & $18-119$ & $53 \pm 1.8$ & $51-55$ \\
\hline carcinogenic PAHs & $15 \pm 9.5$ & $4.0-42$ & $20 \pm 11$ & $5.5-44$ & $21 \pm 0.7$ & $20-21$ \\
\hline Saccharides & $260 \pm 114$ & $99-523$ & $512 \pm 208$ & $140-1170$ & $455 \pm 107$ & $247-562$ \\
\hline Levoglucosan & $194 \pm 89$ & $73-390$ & $388 \pm 109$ & $228-735$ & $371 \pm 84$ & $287-455$ \\
\hline Fatty acids & $972 \pm 309$ & $667-2917$ & $3185 \pm 980$ & $852-9872$ & $2223 \pm 872$ & $1351-3095$ \\
\hline
\end{tabular}

may easily aggravate regional air pollution. The highest $\mathrm{PM}_{2.5}$ concentration $\left(342 \mu \mathrm{g} \mathrm{m}^{-3}\right)$ recorded on the night of 18 January (haze period), was 4.6 times higher than the secondary standard of China's National Ambient Air Quality (75 $\mu \mathrm{g} \mathrm{m}^{-3}, 24 \mathrm{hr}$ average) limit, and 13.7 times higher than the air quality guideline of an 24-hour average of $25 \mu \mathrm{g} \mathrm{m}^{-3}$ by the World Health Organization.

Note that the air masses during haze periods were transported from south such as Jiangsu, Zhejiang, and Henan province to Liaocheng. In addition, the average wind speed was $1.2 \mathrm{~m} \mathrm{~s}^{-1}$ and the RH was $52 \%$ during haze periods, all favoring the accumulation of pollutants and regional air pollution formation. In contrast, air mass during the clean period originated mostly from northwest China.

To assess the impact of fireworks burning on the composition of $\mathrm{PM}_{2.5}$, the $\mathrm{R}_{\mathrm{Lp}}$ and $\mathrm{R}_{\mathrm{La}}$ values of $\mathrm{OC}$ and $\mathrm{EC}$ were calculated. The $\mathrm{R}_{\mathrm{Lp}}$ values of $\mathrm{OC}$ and EC were 2.53 and 0.93 , the $\mathrm{R}_{\mathrm{La}}$ value of $\mathrm{OC}$ and EC were 2.94 and 0.94 , suggesting that fireworks had more impacts on OC than EC. The concentration of OC also increased significantly during haze periods compared with clean periods. To explore the chemical characteristics of OA and the influence of fireworks 
displays, the organic compounds including $n$-alkanes, PAHs, saccharides, and fatty acids in $\mathrm{PM}_{2.5}$ were analyzed during the clean, haze, and LNY periods.

\section{n-Alkanes}

n-Alkanes compounds ranging from $\mathrm{C}_{18}$ to $\mathrm{C}_{36}$ were detected in the $\mathrm{PM}_{2.5}$ samples. The average concentration of total $n$-alkanes was $471 \pm 233 \mathrm{ng} \mathrm{m}^{-3}$ (ranging from 179 to $1251 \mathrm{ng} \mathrm{m}^{-3}$ ), which was about 4.5 times higher than that in the regional background sites of the Yangtze River Delta during the wintertime (Decesari et al., 2006). As shown in Table 1 , the concentration of $n$-alkanes during haze periods $\left(536 \pm 263 \mathrm{ng} \mathrm{m}^{-3}\right)$ was higher than that in clean periods (363 $\pm 116 \mathrm{ng} \mathrm{m}^{-3}$ ) owing to the unfavorable weather conditions. The stagnation conditions with lower wind speed $(1.2 \pm$ $\left.0.4 \mathrm{~m} \mathrm{~s}^{-1}\right)$ and higher RH $(52.3 \pm 12.8 \%)$ in the haze period than those in the clean period (wind speed: $2.9 \pm 0.7 \mathrm{~m} \mathrm{~s}^{-1}$; RH as and $26.1 \pm 10.3 \%$ ) favored the accumulation of $n$-alkanes in $\mathrm{PM}_{2.5}$ (Fig. 2). The concentration of $n$-alkanes during LNY was $391 \pm 78 \mathrm{ng} \mathrm{m}^{-3}$, accounting for $0.23 \%$ of the fine particle mass. The $\mathrm{R}_{\mathrm{Lp}}$ and $\mathrm{R}_{\mathrm{La}}$ values of $n$-alkanes were 0.60 and 0.55 , indicating that the influence of fireworks burning on $n$-alkanes concentration is minor.

As shown in Fig. 4, $\mathrm{C}_{23}$ was the most abundant compound followed by $\mathrm{C}_{24}$ and $\mathrm{C}_{25}$. Carbon preference index (CPI) standing for the relative abundance of compounds containing odd or even number of carbon atoms was used to distinguish the source of plant waxes and fossil fuel emissions (Simoneit, 1986; Rogge et al., 1993a). It is recognized that $n$-alkanes derived from plant wax are characterized by an odd carbon number preference and generally larger than 5 , whereas $n$-alkanes derived from fossil fuel are characterized by a CPI close to unity (Simoneit, 1984b; Rogge et al., 1993a; Feng et al., 2006). The $n$-alkanes in this study displayed little oddeven preference with a CPI in the range of 0.9-1.8 (Table 1), indicating that the $n$-alkanes in $\mathrm{PM}_{2.5}$ from Liaocheng were mainly produced from fossil fuels combustion.

To estimate the source strength of plant wax versus fossil fuel for producing $n$-alkanes, the concentration of plant wax $n$-alkanes can be calculated from the following equation (Simoneit et al., 1991):

$\operatorname{Wax} \mathrm{C}_{n}=\mathrm{C}_{n}-\left(\mathrm{C}_{n-1}+\mathrm{C}_{n+1}\right)$

where Wax $\mathrm{C}_{n}$ was the concentration of the plant wax nalkane with carbon number $\mathrm{n} . \mathrm{C}_{n-1}, \mathrm{C}_{n}$ and $\mathrm{C}_{n+1}$ are the concentrations of $n$-alkanes with the specified carbon numbers. Negative values of $\mathrm{C}_{n}$ were taken as zero.

The average concentrations of plant wax $n$-alkanes were much lower than that of fossil fuels $n$-alkanes (Table 1 ), and the contribution of plant wax to the total $n$-alkanes were $11.7 \%, 13.3 \%$, and $11.8 \%$ during clean, haze, and LNY periods, respectively, which implied the dominance of anthropogenic $n$-alkanes from vehicle emission and coal burning (Simoneit, 1984a).

\section{PAHs}

PAH Concentrations in Ambient Air

A total of 14 kinds of polycyclic aromatic hydrocarbons
(PAHs) were detected in the $\mathrm{PM}_{2.5}$ samples from Liaocheng. As shown in Table 1, total PAHs varied from 12 to 119 $\mathrm{ng} \mathrm{\textrm {m } ^ { - 3 }}$ with an average of $48 \pm 25 \mathrm{ng} \mathrm{m}^{-3}$, which is much lower than that in Jinan $\left(105.3 \mathrm{ng} \mathrm{m}^{-3}\right)$ in the similar meteorological period of 2016 (Li et al., 2017), but higher than that in Nanjing $\left(17.21 \pm 13.21 \mathrm{ng} \mathrm{m}^{-3}\right)$ (Kong et al., 2015a), Nanchang $\left(22.54 \pm 8.47 \mathrm{ng} \mathrm{m}^{-3}\right.$ ) (Liu et al., 2016), and Guangzhou $\left(23.7 \pm 18.4 \mathrm{ng} \mathrm{m}^{-3}\right)$ (Li et al., 2006), for coal combustion was one of the most important sources of PAHs in North China during the heating season (Simoneit et al., 1991). The total concentrations of PAHs during the haze period were 1.4 times higher than those in the clean period (Table 1) due to the stagnant meteorological conditions (Fig. 2) (Li and Zhang, 2014).

During the whole period of observation, the PAHs concentrations had no significant correlations with the $\mathrm{PM}_{2.5}$ concentrations $\left(R^{2}=0.32, P<0.01\right)$, which implied that not only the emission sources but also the gas-particle partitioning processes control the variations of the particulate PAHs concentrations (Sitaras et al., 2004; Zhu et al., 2015). The PAHs concentrations were higher in the nighttime (54.9 $\left.\pm 29.1 \mathrm{ng} \mathrm{m}^{-3}\right)$ than those in the daytime $\left(40.9 \pm 17.6 \mathrm{ng} \mathrm{m}^{-3}\right)$, because the lower temperature (daytime: $3.8^{\circ} \mathrm{C}$; nighttime: $1.5^{\circ} \mathrm{C}$ ) (Fig. 2) are favorable for the transition of PAHs from the vapour phase to the particle phase (Li et al., 2014), and the weaker solar radiation suppresses the photochemical decomposition of PAHs during the nighttime (Duan et al., 2007). In addition, the accumulation process enhanced by the decreased inversion layers at night was another important reason for the higher concentrations of PAHs in the nighttime compared to that in the daytime (Li et al., 2012).

As indicated in Fig. 3, the most abundant PAH congener was Fluoranthene (Flu), followed by Benzo(b)fluorantheSne (BbF), and Chrysene (Chr), and the lowest PAH was Ant, whose concentration was around 14 times less abundant than the highest species. The 14 PAHs can be classified on the basis of the number of aromatic rings as low molecular weight [LMW, 3-ring (Phe, Ant) and 4-ring (Flu, Pyr, BaA, and $\mathrm{Chr}$ )] and high molecular weight [HMW, 5-ring (BbF, $\mathrm{BkF}, \mathrm{BeP}, \mathrm{BaP}, \mathrm{Per}$, and DBA) and 6-ring (IP and BghiP)] (Wang et al., 2012). The distribution of ring number of PAHs were presented in Fig. 4. LMW species were dominant in each sampling period that accounted for about $54 \%$ of the total PAHs on average. Previous studies revealed that the major sources of LMW PAHs were from the combustion of grass, wood, and coal (Sorooshian et al., 2007; Lin et al., 2015; Ren et al., 2017a), while HMW PAHs was significantly derived from the emissions of vehicle exhausts (Kong et al., 2015a; Li et al., 2017). These results implied the important contribution of coal combustion and biomass burning to the total concentrations of PAHs in this study.

\section{Source Identification of PAHs by Diagnostic Ratios}

To identify the sources of PAHs, diagnostic ratios such as Ant/(Ant + Phe $),$ Flu/(Flu + Pyr $), \mathrm{BaA} /(\mathrm{BaA}+\mathrm{Chr})$, $\mathrm{IP} /(\mathrm{IP}+\mathrm{BghiP})$, and $\mathrm{BaP} / \mathrm{BeP}$ were calculated as shown in Table 2. Wang et al. (2008) and Kong et al. (2015a) have suggested that the mass ratio of $\mathrm{Ant} /(\mathrm{Ant}+\mathrm{Phe})$ is less than 0.10 when petroleum consumed by vehicles is predominant, 

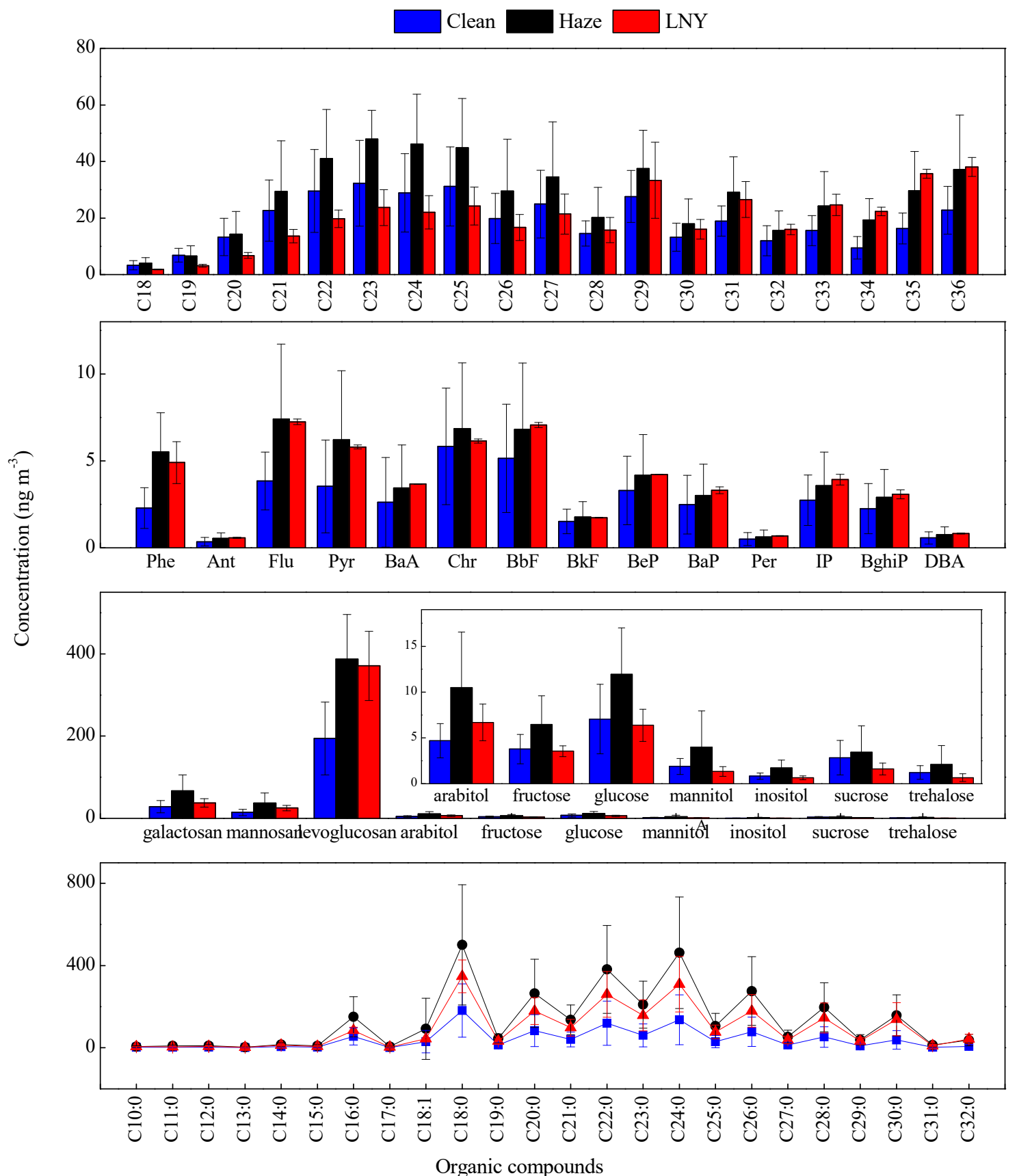

Fig. 3. Molecular composition and concentration of organic compounds in $\mathrm{PM}_{2.5}$ samples in Liaocheng during the clean, haze, and Lunar New Year periods.

and the opposite is the fossil fuels combustion source. As shown in Table 2, the ratios of Ant/(Ant + Phe) in the Liaocheng atmosphere were in the range of $0.05-0.16$, suggesting that PAHs in Liaocheng samples were mostly derived from petroleum consumption and fossil fuels combustion. Ratios of Flu/(Flu + Pyr) close to 0.4 imply petroleum sources, ranging from 0.4 to 0.5 indicate petroleum combustion, and higher than 0.5 indicate coal or biomass burning (Gu et al., 2010; Kong et al., 2015a). In this study, the $\mathrm{Flu} /(\mathrm{Flu}+\mathrm{Pyr})$ ratios were greater than 0.5 during the whole sampling period, indicating that coal and biomass burning were the dominated sources of PAHs. The ratios of
$\mathrm{BaA} /(\mathrm{BaA}+\mathrm{Chr})$ ranged from 0.20 to 0.45 , similar to the values for gasoline (0.22-0.55) and diesel (0.38-0.64) emissions (Kong et al., 2015a). The ratios of IP/(IP + BghiP) has been reported as less than 0.4 for vehicle emissions ( 0.18 for gasoline and 0.38 for diesel), and higher than 0.5 for the mixture of coal combustion and biomass burning (Grimmer et al., 1981; Feng et al., 2012). In this study, the diagnostic ratios of IP/(IP + BghiP) were 0.58, 0.56, and 0.56 during clean, haze, and LNY periods, respectively, suggesting that PAHs were mostly derived from coal combustion and biomass burning. The ratio of $\mathrm{BaP} / \mathrm{BeP}$ can be used as an indicator of the photochemical aging of 


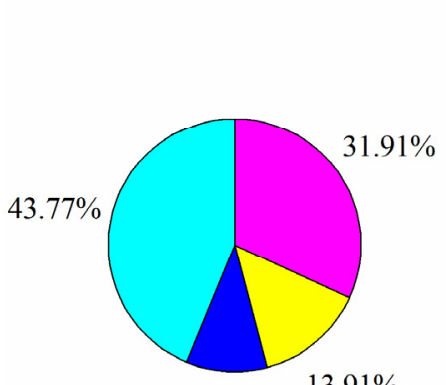

$10.42 \%$ $\square$ 3-ring $\square$ 4-ring $\square$ 5-ring $\square$ 6-ring

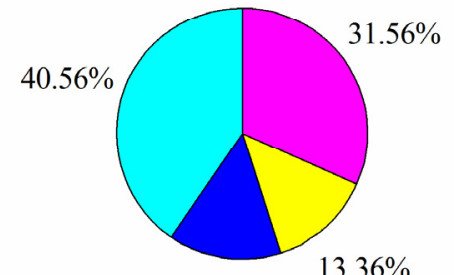

$14.52 \%$

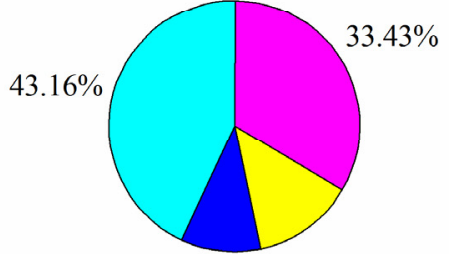

$13.14 \%$

$10.27 \%$

Clean

Haze

LNY

Fig. 4. Distribution of ring number of PAHs in $\mathrm{PM}_{2.5}$ samples in Liaocheng during the clean, haze, and Lunar New Year periods.

Table 2. Diagnostic ratios of $P A H s$ detected in the $\mathrm{PM}_{2.5}$ samples in Liaocheng City.

\begin{tabular}{|c|c|c|c|c|c|c|}
\hline & \multicolumn{2}{|l|}{ Clean period } & \multicolumn{2}{|l|}{ Haze period } & \multicolumn{2}{|l|}{ LNY period } \\
\hline & Average & Range & Average & Range & Average & Range \\
\hline Ant/(Ant + Phe) & $0.10 \pm 0.03$ & $0.06-0.13$ & $0.09 \pm 0.03$ & $0.05-0.16$ & $0.11 \pm 0.02$ & $0.09-0.13$ \\
\hline Flu/(Flu + Pyr) & $0.55 \pm 0.00$ & $0.55-0.56$ & $0.56 \pm 0.01$ & $0.54-0.58$ & $0.56 \pm 0.00$ & $0.56-0.57$ \\
\hline $\mathrm{BaA} /(\mathrm{BaA}+\mathrm{Chr})$ & $0.21 \pm 0.02$ & $0.20-0.22$ & $0.32 \pm 0.05$ & $0.24-0.45$ & $0.37 \pm 0.01$ & $0.37-0.38$ \\
\hline IP/(IP + BghiP) & $0.58 \pm 0.01$ & $0.57-0.59$ & $0.56 \pm 0.02$ & $0.48-0.58$ & $0.56 \pm 0.00$ & $0.55-0.56$ \\
\hline $\mathrm{BaP} / \mathrm{BeP}$ & $0.84 \pm 0.01$ & $0.79-0.85$ & $0.70 \pm 0.08$ & $0.60-0.88$ & $0.77 \pm 0.05$ & $0.74-0.83$ \\
\hline
\end{tabular}

organic aerosols, because $\mathrm{BaP}$ is more reactive than $\mathrm{BeP}$ in the atmosphere (Li et al., 2009; Huang et al., 2012; Kong et $a l ., 2015 \mathrm{a})$. It could be found that the lowest $\mathrm{BaP} / \mathrm{BeP}$ value occurred in haze periods $(0.70 \pm 0.01)$, largely because the higher temperature and $\mathrm{RH}$ conditions (Fig. 2) are favourable for photochemical oxidation of aerosols. The mean value of $\mathrm{BaP} / \mathrm{BeP}$ in Liaocheng $(0.75 \pm 0.07)$ was similar to that of Xi'an (0.80 \pm 0.10$)$ (Li et al., 2014) and Beijing (0.72-0.93) (Li et al., 2013c), which were both much lower than that over the Qinghai Lake (0.22) (Li et al., 2013a), reflecting that aerosols in the urban area were less oxidized than the high altitude regions due to the weaker solar radiation.

\section{Health Risk Assessment of PAHs Pollution}

PAHs, the products of incomplete combustion of carboncontaining materials, are of high toxicity and carcinogenicity (Huang et al., 2018). Yang et al. (2017a) have demonstrated that the carcinogenic potency of PAHs in winter was approximately 6.21 times higher than that in summer. The concentrations of carcinogenic PAHs including $\mathrm{BaA}, \mathrm{BbF}$, $\mathrm{BkF}, \mathrm{BaP}, \mathrm{InP}$, and DBA during the haze and LNY periods were more than three times higher than those in the clean period (Table 1), indicating PAHs were more carcinogenic during these two periods. As the classical chemical carcinogen, $\mathrm{BaP}$ is considered as one of the most powerful mutagens, $\mathrm{BaP}$ concentration was $3.1 \pm 1.5 \mathrm{ng} \mathrm{m}^{-3}$ during the sampling periods, which about three times higher than the standard of World Health Organization $\left(1 \mathrm{ng} \mathrm{m}^{-3}\right)$. The BaP equivalent concentration (BaPeq) is typically employed to assess the carcinogenic potency of PAHs. The concentrations of carcinogenic PAHs were calculated as follows (Zhu et al., 2015):
$\mathrm{BaPeq}_{\mathrm{i}}=\mathrm{PAH}_{\mathrm{i}} \times \mathrm{TEF}_{\mathrm{i}}$

$$
\mathrm{TEQ}=\sum \mathrm{BaPeq}_{\mathrm{i}}
$$

where $\mathrm{BaPeq}_{\mathrm{i}}$ is the $\mathrm{BaP}$ equivalent concentration of the $i$ th congener $\mathrm{PAH} ; \mathrm{PAH}_{\mathrm{i}}$ is the concentration of the $i$ th congener PAH, TEF is the toxic equivalent factor for the $i$ th congener PAH, and TEQ is the toxic equivalent of the target compound. The average concentration of TEQ was $5.69 \pm$ $2.7 \mathrm{ng} \mathrm{m}^{-3}$ during the sampling period, which was much higher than that in the cities of southern China such as Hong Kong (0.64 $\mathrm{ng} \mathrm{m}^{-3}$ ) (Zheng and Fang, 2000) and Guangzhou $\left(2.15 \mathrm{ng} \mathrm{m}^{-3}\right.$ ) (Ren et al., 2017b) in winter. Nonetheless, the TEQ value was much lower than that in heavily polluted cities of North China, such as Xi' an $\left(55.4 \mathrm{ng} \mathrm{m}^{-3}\right)$ (Li et al., 2014), Beijing (45.99 $\mathrm{ng} \mathrm{m}^{-3}$ ) (Li et al., 2013c), and Jinan $\left(10.88 \mathrm{ng} \mathrm{m}^{-3}\right.$ ) (Li et al., 2017). These results illustrate that the increased health risks associated with the high PAHs loading during the winter heating season, thus people living in the cities of northern China have a greater inhalation cancer risk due to PAHs exposure. As shown in Fig. 5, the averaged TEQ showed the following trend as haze period $\left(6.32 \pm 2.57 \mathrm{ng} \mathrm{m}^{-3}\right)>\operatorname{LNY}\left(5.89 \pm 0.27 \mathrm{ng} \mathrm{m}^{-3}\right)>$ clean period $\left(1.97 \pm 0.55 \mathrm{ng} \mathrm{m}^{-3}\right)$, further indicating that PAHs have more carcinogenic and mutagenic effects during haze and LNY periods. Additionally, the TEQ value was higher during the nighttime than that during the daytime in the whole period (Fig. 5), suggesting a higher potential carcinogenic effect of PAHs at nighttime than daytime due to the accumulation process.

The exposure risks of PAHs in gas and particle phases were calculated using the incremental lifetime cancer risk 


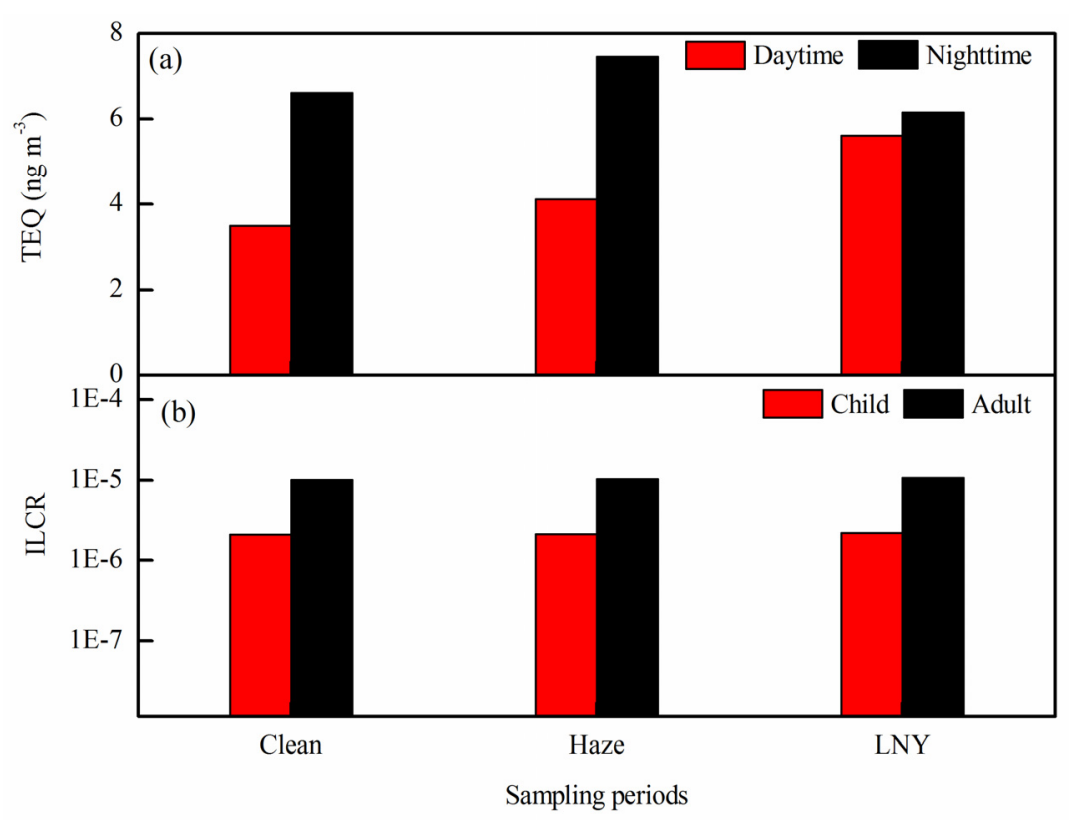

Fig. 5. Toxic equivalent concentrations (TEQ) and incremental lifetime cancer risk (ILCR) for children and adult during the clean, haze, and Lunar New Year periods.

(ILCR) based on the standard model established by the United States Environmental Protection Agency (Gao et al., 2018; Zhang et al., 2019), the ILCR was calculated from the following equation:

$$
I L C R_{\text {inhalation }}=C S F_{\text {inhalation }} \times \frac{C \times I R_{\text {inhalation }} \times E D \times E F}{B W \times A L T}
$$

where $\mathrm{CSF}_{\text {inhalation }}$ is inhalation carcinogenic slope factor of $\mathrm{BaP}\left(3.14 \mathrm{mg} \mathrm{kg}^{-1} \mathrm{day}^{-1}\right), \mathrm{C}$ is the sum of converted PAHs concentrations based on TEQ values, $\mathrm{IR}_{\text {inhalation }}$ is the inhalation rate $\left(7.6 \mathrm{~m}^{3}\right.$ day $^{-1}$ for children and $20 \mathrm{~m}^{3}$ day $^{-1}$ for adults), ED is the lifetime exposure duration ( 6 years for children and 52 years for adults), EF is the exposure frequency (1 day year ${ }^{-1}$ for $\left.\mathrm{CNY}\right)$; BW is the body weight ( $15 \mathrm{~kg}$ for children and $70 \mathrm{~kg}$ for adults); ALT is the average life span for carcinogens (25,550 days for both children and adults). The mean of inhalation ILCR for Liaocheng citizens was shown in Fig. 5. According to most regulatory programs for carcinogen risk assessment, the virtual safety was denoted with an ILCR of $10^{-6}$ or less, while the values of ILCR range from $10^{-6}$ to $10^{-4}$ indicated potential risk, and a potentially high risk was estimated by an ILCR of greater than $10^{-4}$ (Wang et al., 2011; Pongpiachan, 2016). In this study, the estimated ILCR for children and adults were $2.13 \times 10^{-6}$ and $1.04 \times 10^{-5}$, respectively, suggesting a moderate potential carcinogenic risk to human in Liaocheng. Fortunately, the ILCR for children was less than $10^{-6}$ during clean periods, indicating that it is relatively safe for children to expose to $\mathrm{PM}_{2.5}$-bound PAHs during the clean period. But the ILCR for both children and adults during LNY and haze periods were about 3.0 and 3.2 times higher than that during the clean period, highlighting the importance of air pollution to human health.

\section{Saccharides}

A total of 10 kinds of saccharides, including three anhydrosugars (galactosan, mannosan, and levoglucosan), four primary sugars (fructose, glucose, sucrose, and trehalose), and three sugar alcohols (arabitol, mannitol, and inositol) were detected in the $\mathrm{PM}_{2.5}$ samples. The concentrations of total sugars showed the following trend as LNY $(455 \pm 107$ $\left.\mathrm{ng} \mathrm{\textrm {m } ^ { - 3 }}\right)>$ haze period $\left(512 \pm 208 \mathrm{ng} \mathrm{m}^{-3}\right)>$ clean period $\left(260 \pm 114 \mathrm{ng} \mathrm{m}^{-3}\right)$ (Table1), which was largely owing to the significant contribution of levoglucosan. Levoglucosan was the most abundant saccharides species, accounting for $74.8 \%, 75.8 \%$, and $81.6 \%$ of the total saccharides in clean, haze, and LNY periods, respectively. Levoglucosan is chemically stable in the atmosphere and originates from thermal splitting of cellulose at temperature $\geq 300^{\circ} \mathrm{C}$, thus it can be considered as a key tracer for biomass-burning (Simoneit et al., 2004a; Mochida et al., 2010). Moreover, levoglucosan was significantly correlated with $\mathrm{K}^{+}\left(R^{2}=\right.$ $0.89, P<0.01$ ) (unpublished data), which mostly originated from biomass burning. Galactosan and mannosan, the isomers of levoglucosan, are thermal decomposition products of hemicellulose (Simoneit, 2002), thus they are also the tracers for smoke from biomass (Oros et al., 2006). As shown in Fig. 3, all of the three anhydrosugars exhibited higher concentrations during haze and LNY periods than those in the clean period, confirming that air quality during haze and LNY periods were more significantly influenced by biomass burning. In addition, the stagnant meteorological conditions is favorable for the accumulation of pollutants (Fig. 2).

Primary saccharides and sugar alcohols totally account for $6.16 \%$ of the saccharides in this study. Glucose was the dominant saccharide compound except for anhydrosaccharides, which originated in different sources such as soil and biological particles as well as biomass burning (Wan and Yu, 2007). The ratio of glucose/levoglucosan (G/L) 
can be used to estimate the contribution of different sources (Nirmalkar et al., 2015b). Previous studies (Medeiros et al., 2006) have reported that the ratio of $G / L$ was about 4.5 for smoke free samples, while the ratio of $\mathrm{G} / \mathrm{L}$ was significantly lower (0.03) for vegetative burning (Medeiros and Simoneit, 2008). In this study, the ratio of $\mathrm{G} / \mathrm{L}$ ranged from $0.01-0.04$ with a mean of 0.02 , indicating that glucose was mostly attributed to biomass burning in the Liaocheng $\mathrm{PM}_{2.5}$ aerosols. Interestingly, the concentration of sucrose increased sharply during LNY $\left(\mathrm{R}_{\mathrm{Lp}}>1\right.$ ), a recent study (Yang et al., 2017b) showed that manufacturers add sucrose to firecrackers in order to increase the loudness of firecrackers. Sugar alcohol were more abundant in fine aerosols during winter (Liang et al., 2016). Arabitol and mannitol, the dominant sugar alcohol, whose concentrations ( 8.4 and $3.2 \mathrm{ng} \mathrm{m}^{-3}$, respectively) were much higher than those in the Taklimakan desert (1.5 and $0.27 \mathrm{ng} \mathrm{m}^{-3}$, respectively) (Fu et al., 2016), likely associated with biomass burning activities.

\section{Fatty Acids}

Twenty-four fatty acids $\left(\mathrm{C}_{10: 0}-\mathrm{C}_{32: 0}\right.$, and $\left.\mathrm{C}_{18: 1}\right)$ were detected in the $\mathrm{PM}_{2.5}$ samples. The concentrations of fatty acids were in the range of 668-9872 $\mathrm{ng} \mathrm{m}^{-3}$ with an average concentration of $2679 \pm 1695 \mathrm{ng} \mathrm{m}^{-3}$. The concentrations of fatty acids during the haze $\left(3185 \pm 980 \mathrm{ng} \mathrm{m}^{-3}\right)$ and LNY $\left(2223 \pm 872 \mathrm{ng} \mathrm{m}^{-3}\right)$ periods were more than two times higher than those in the clean period $\left(972 \pm 309 \mathrm{ng} \mathrm{m}^{-3}\right)$, respectively. As shown in Fig. 3, $\mathrm{C}_{18: 0}$ was the most abundant acid followed by $\mathrm{C}_{24: 0}$ during the sampling period. It has been found that LMW fatty acids $\left(\mathrm{C}_{12: 0}-\mathrm{C}_{19: 0}\right)$ with the major peak of $\mathrm{C}_{16: 0} / \mathrm{C}_{18: 0}$ are mostly derived from cooking activities in the urban aerosols (Li et al., 2014), while HMW fatty acids $\left(\mathrm{C}_{20: 0}-\mathrm{C}_{34: 0}\right)$ largely originate in vascular plant wax (Simoneit, 1986; Mochida et al., 2003; Simoneit et al., 2004b). Octadecenoic acid $\left(\mathrm{C}_{18: 1}\right)$ is unstable and it can be rapidly degraded in the atmosphere, thus the ratio of octadecenoic acid $\left(\mathrm{C}_{18: 1}\right)$ to octadecanoic acid $\left(\mathrm{C}_{18: 0}\right)$ was used to indicate the ageing of aerosols. The ratio of $\mathrm{C}_{18: 1} / \mathrm{C}_{18: 0}$ was $0.17 \pm$ $0.01,0.11 \pm 0.03$ and $0.13 \pm 0.02$ during clean, haze, and LNY periods, respectively, indicating that aerosols in haze periods were more oxidized, which is consistent with the results of $\mathrm{BaP} / \mathrm{BeP}$ ratios. No significant diurnal variations of $\mathrm{C}_{18: 1} / \mathrm{C}_{18: 0}$ ratio was found in Liaocheng during winter (daytime: 0.11 ; nighttime: 0.12 ). Similar results were also reported on the aerosols from New Delhi (Li et al., 2014), where the winter aerosols were found to be much oxidized.

\section{Source Estimates from PCA-MLR}

Principal component analysis (PCA) was employed to identify the sources of organic compounds in the Liaocheng $\mathrm{PM}_{2.5}$ samples. In order to further determine the relative contribution of different sources, multiple linear regression (MLR) was applied following the PCA. Detailed methods for PCA-MLR model were described in previous studies (Larsen and Baker, 2003). As showen in Table 3, PCA factors for the clean, haze, and LNY period totally explaining $83 \%, 98 \%$, and $90 \%$ of the data variance, respectively. As for clean periods, factor 1 shows high loading with PAHs including low molecular weight and higher molecular weight PAHs, which were mainly related to fossil fuels combustion sources including coal and vehicles; while factor 2 represents plant wax source as it highly correlates

Table 3. Principal component analysis for major species in $\mathrm{PM}_{2.5}$ aerosols collected in Liaocheng City.

\begin{tabular}{|c|c|c|c|c|c|c|}
\hline \multirow{2}{*}{ Compound } & \multicolumn{2}{|c|}{ Clean period } & \multicolumn{2}{|c|}{ Haze period } & \multicolumn{2}{|c|}{ LNY period } \\
\hline & Factor 1 & Factor 2 & Factor 1 & Factor 2 & Factor 1 & Factor 2 \\
\hline LMW $n$-alkane $\left(\mathrm{C}_{23}\right)$ & 0.62 & -0.25 & 0.56 & 0.48 & 0.51 & 0.19 \\
\hline HMW $n$-alkanes $\left(\mathrm{C}_{36}\right)$ & -0.25 & 0.88 & 0.07 & 0.04 & 0.47 & -0.82 \\
\hline Ant & 0.74 & -0.42 & 0.91 & 0.23 & 0.43 & 0.01 \\
\hline Flu & 0.51 & -0.35 & 0.96 & 0.33 & 0.48 & 0.55 \\
\hline Pyr & 0.57 & -0.27 & 0.95 & 0.32 & 0.46 & 0.59 \\
\hline $\mathrm{BaA}$ & 0.88 & 0.40 & 0.79 & 0.48 & 0.91 & 0.03 \\
\hline Chr & 0.94 & 0.27 & 0.80 & 0.49 & 0.81 & -0.01 \\
\hline $\mathrm{BbF}$ & 0.97 & 0.24 & 0.68 & 0.48 & 0.85 & -0.04 \\
\hline $\mathrm{BkF}$ & 0.96 & 0.16 & 0.42 & 0.75 & 0.48 & 0.09 \\
\hline Bep & 0.97 & 0.21 & 0.49 & 0.75 & 0.36 & -0.03 \\
\hline Bap & 0.96 & 0.20 & 0.36 & 0.72 & 0.40 & 0.13 \\
\hline Per & 0.90 & 0.23 & 0.41 & 0.57 & 0.32 & 0.19 \\
\hline IP & 0.91 & -0.14 & 0.26 & 0.97 & 0.32 & 0.11 \\
\hline BghiP & 0.95 & -0.16 & 0.32 & 0.93 & 0.41 & 0.13 \\
\hline DBA & 0.90 & -0.09 & 0.21 & 0.94 & 0.22 & 0.08 \\
\hline levoglucosan & 0.25 & 0.49 & 0.74 & 0.13 & 0.40 & 0.61 \\
\hline sucrose & 0.24 & 0.31 & 0.45 & 0.15 & 0.36 & 0.87 \\
\hline LMW fatty acid $\left(\mathrm{C}_{18: 0}\right)$ & 0.23 & 0.45 & 0.49 & 0.13 & 0.93 & 0.29 \\
\hline HMW fatty acid $\left(\mathrm{C}_{24: 0}\right)$ & 0.23 & 0.92 & 0.02 & 0.12 & 0.11 & -0.02 \\
\hline Source & $\begin{array}{l}\text { Fossil fuels } \\
\text { combustion }\end{array}$ & Plant wax & $\begin{array}{l}\text { coal burning }+ \\
\text { biomass burning }\end{array}$ & vehicle & $\begin{array}{l}\text { coal burning }+ \\
\text { cooking }\end{array}$ & $\begin{array}{l}\text { firework burning }+ \\
\text { biomass burning }\end{array}$ \\
\hline Contribution & $63 \%$ & $37 \%$ & $65 \%$ & $35 \%$ & $55 \%$ & $45 \%$ \\
\hline
\end{tabular}

Note: absolute values higher than 0.5 are highlighted in boldface. 
with low molecular weight $n$-alkanes and high molecular weight fatty acid. As for haze periods, two components were identified. Factor 1 was mixed of coal combustion and biomass burning as it shows a high loading with LMW PAHs and levoglucosan. As discussed above, Flu, Pyr, and levoglucosan were emitted from biomass burning (Zhang et al., 2010; Lin et al., 2015; Ren et al., 2017a), and BbF was the dominant species in coal combustion smokes (Wang et al., 2006, 2007a); factor 2 represents the vehicle source as it showed high loading with HMW PAHs such as BkF, BaP, IP, and BghiP, which are mostly derived from diesel and gasoline vehicle (Wang et al., 2010). For the LNY period, factor 1 represents the coal burning and cooking source, because it shows a high loading with $\mathrm{BbF}$ and low molecular weight fatty acid as it drieved from cooking activities. Sucrose was an additive in firecrackers, thus factor 2 represents firework burning and biomass burning emission since it shows a high loading with sucrose, Flu, Pyr, and levoglucosan.

MLR was applied to determine the contribution of different sources after identifying the four factors by PCA. The regression analyzes the following equation:

$$
\begin{array}{ll}
\mathrm{Z}_{1}=0.876 \mathrm{~F}_{1}+0.517 \mathrm{~F}_{2} & \left(\mathrm{R}^{2}=0.99\right) \\
\mathrm{Z}_{2}=0.835 \mathrm{~F}_{1}+0.455 \mathrm{~F}_{2} & \left(\mathrm{R}^{2}=0.86\right) \\
\mathrm{Z}_{3}=0.697 \mathrm{~F}_{1}+0.560 \mathrm{~F}_{2} & \left(\mathrm{R}^{2}=0.95\right)
\end{array}
$$

Therefore, the average percent contribution during clean periods is $63 \%$ for the fossil fuels combustion (Factor 1), $17 \%$ for the plant wax source (Factor 2). The mean contribution during haze periods is $65 \%$ for coal burning and biomass burning emissions (Factor 1), 35\% for the vehicular source (Factor 2). For the LNY period, the mean percent contribution is 55\% for the coal burning and cooking activity (Factor 1), 45\% for the firework burning and biomass burning emissions (Factor 2).

\section{CONCLUSIONS}

$\mathrm{PM}_{2.5}$ aerosols from Liaocheng the in North China Plain during a winter haze episode around 2017 Chinese Spring Festival were analyzed for $n$-alkanes, PAHs, saccharides, and organic acids to investigate the molecular distributions of organic aerosol as well as to assess the impacts of fireworks burning on aerosol chemical components and human health risk levels. The mean concentration of $\mathrm{PM}_{2.5}$ during the haze period $\left(162 \pm 66 \mu \mathrm{g} \mathrm{m}^{-3}\right)$ and LNY $\left(174 \pm 49 \mu \mathrm{g} \mathrm{m}^{-3}\right)$ were about 2.2 and 2.3 times higher than the secondary standard of China's National Ambient Air Quality limit, respectively, indicating that Liaocheng was suffering from serious air pollution. $\mathrm{PM}_{2.5}$ concentration in LNY's Eve was 1.8 times higher than that during the daytime of the LNY (no fireworks), suggesting that fireworks burning has significant impacts on fine particle pollution. During the haze period, a sharp increase in $n$-alkanes, PAHs, saccharides, and fatty acids were observed, but the influence of fireworks burning on $n$-alkanes concentration is minor. $\mathrm{C}_{23}$ was the most abundant n-alkane followed by $\mathrm{C}_{24}$ and $\mathrm{C}_{25}$ in $\mathrm{PM}_{2.5}$ throughout the entire study period. The CPI was in the range of $0.8-1.7$, and $\% \mathrm{Wax}_{n}$ were $13.2 \%, 22.5 \%$, and $11.8 \%$ during clean, haze, and LNY periods, respectively, indicating that the aerosol $n$-alkanes in Liaocheng were mainly produced from fossil fuels combustion. The concentrations of carcinogenic PAHs during haze and LNY periods were more than three times higher than those in the clean period, indicating that PAHs were more carcinogenic during the two periods. In addition, the estimated ILCR for children and adults were both about three times higher than those in the clean period, suggesting a moderate potential carcinogenic risk in Liaocheng. Levoglucosan, galactosan, and mannosan were the most abundant saccharides, contributing $93.84 \%$ of the total concnrtrations of saccharides, confirming that the saccharides in $\mathrm{PM}_{2.5}$ from Liaocheng were significantly influenced by biomass burning. Both ratios of $\mathrm{BaP} / \mathrm{BeP}$ and $\mathrm{C}_{18: 1} / \mathrm{C}_{18: 0}$ suggest that aerosols in the haze period were more oxidized than those in the clean and LNY periods. According to the source precise molecular tracers and PCA-MLR model, coal combustion, biomass burning, and vehicle emissions were the major sources of organic compounds in $\mathrm{PM}_{2.5}$ aerosols during winter in Liaocheng, cooking activity and firework burning had impact on organic aerosols obviously during LNY.

\section{ACKNOWLEDGMENTS}

This work was supported by the National Science Foundation of China (Grant No. 41505112 and 41773117), Natural Science Foundation of Shandong Province (Grant No. BS2015HZ002), the National Natural Science Foundation of China for Distinguished Young Scholars (No.41325014) and Open Funds of State Key Laboratory of Loess and Quaternary Geology, Institute of Earth Environment, Chinese Academy of Sciences (Grant Nos. SKLLQG1509 and SKLLQG1504).

\section{REFERENCES}

Chen, F., Zhang, X., Zhu, X., Zhang, H., Gao, J. and Hopke, P.K. (2017). Chemical characteristics of $\mathrm{PM}_{2.5}$ during a 2016 winter haze episode in Shijiazhuang, China. Aerosol Air Qual. Res. 17: 368-380.

Decesari, S., Fuzzi, S., Facchini, M.C., Mircea, M., Emblico, L. and Cavalli, F. (2006). Characterization of the organic composition of aerosols from Rondônia, Brazil, during the LBA-SMOCC 2002 experiment and its representation through model compounds. Atmos. Chem. Phys. 5: 5678-5680.

Duan, J., Bi, X., Tan, J., Sheng, G. and Fu, J. (2007). Seasonal variation on size distribution and concentration of PAHs in Guangzhou city, China. Chemosphere 67: 614-622.

Feng, J., Hu, M., Chan, C.K., Lau, P.S., Fang, M., He, L. and Tang, X. (2006). A comparative study of the organic matter in $\mathrm{PM}_{2.5}$ from three Chinese megacities in three different climatic zones. Atmos. Environ. 40: 3983-3994. Feng, J., Cai, Y., Hu, X., Zhao, W., Wu, M. and Fu, J. 
(2012). The chemical composition and sources of $\mathrm{PM}_{2.5}$ during the 2009 Chinese New Year's holiday in Shanghai. Atmos. Res. 118: 435-444.

Feng, J., Hu, J., Xu, B., Hu, X., Sun, P., Han, W., Gu, Z., $\mathrm{Yu}, \mathrm{X}$. and Wu, M. (2015). Characteristics and seasonal variation of organic matter in $\mathrm{PM}_{2.5}$ at a regional background site of the Yangtze River Delta region, China. Atmos. Environ. 123: 288-297.

Feng, J., Yu, H., Su, X., Liu, S., Li, Y., Pan, Y. and Sun, J.H. (2016). Chemical composition and source apportionment of $\mathrm{PM}_{2.5}$ during Chinese Spring Festival at Xinxiang, a heavily polluted city in North China: Fireworks and health risks. Atmos. Res. 182: 176-188.

Fu, P., Zhuang, G., Sun, Y., Wang, Q., Chen, J., Ren, L., Yang, F., Wang, Z., Pan, X. and Li, X. (2016). Molecular markers of biomass burning, fungal spores and biogenic SOA in the Taklimakan desert aerosols. Atmos. Environ. 130: 64-73.

Gao, Y., Yang, L., Chen, J., Li, Y., Jiang, P., Zhang, J., Yu, H. and Wang, W. (2018). Nitro and oxy-PAHs bounded in $\mathrm{PM}_{2.5}$ and $\mathrm{PM}_{1.0}$ under different weather conditions at Mount Tai in Eastern China: Sources, long-distance transport, and cancer risk assessment. Sci. Total Environ. 622-623: 1400-1407.

Grimmer, G., Jacob, J., Naujack, K.W. and Dettbarn, G. (1981). Profile of the polycyclic aromatic hydrocarbons from used engine oil - inventory by GCGC/MS - PAH in environmental materials, Part 2. Fresenius Z. Anal. Chem. 309: 13-19.

Gu, Z., Feng, J., Han, W., Li, L., Wu, M., Fu, J. and Sheng, G. (2010). Diurnal variations of polycyclic aromatic hydrocarbons associated with $\mathrm{PM}_{2.5}$ in Shanghai, China. J. Environ. Sci. 22: 389-396.

Hallquist, M., Wenger, J.C., Baltensperger, U., Rudich, Y., Simpson, D., Claeys, M., Dommen, J., Donahue, N.M., George, C., Goldstein, A.H., Hamilton, J.F., Herrmann, H., Hoffmann, T., Iinuma, Y., Jang, M., Jenkin, M.E., Jimenez, J.L., Kiendler-Scharr, A., Maenhaut, W., McFiggans, G., Mentel, T.F., Monod, A., Prevot, A.S.H., Seinfeld, J.H., Surratt, J.D., Szmigielski, R. and Wildt, J. (2009). The formation, properties and impact of secondary organic aerosol: current and emerging issues. Atmos. Chem. Phys. 9: 5155-5236.

Huang, K., Zhuang, G., Lin, Y., Wang, Q., Fu, J.S., Zhang, R., Li, J., Deng, C. and Fu, Q. (2012). Impact of anthropogenic emission on air quality over a megacity revealed from an intensive atmospheric campaign during the Chinese Spring Festival. Atmos. Chem. Phys. 12: 17151-17185.

Huang, K.L., Tsai, T.H., Chen, S.J., Chao, H.R., Kuo, Y.M. and Tsai, J.H. (2018). Gas- and water-phase pahs emitted from a single hydrogen-oxygen pem fuel cell. Aerosol Air Qual. Res. 18: 433-443.

Huang, R.J., Zhang, Y., Bozzetti, C., Ho, K.F., Cao, J.J., Han, Y., Daellenbach, K.R., Slowik, J.G., Platt, S.M., Canonaco, F., Zotter, P., Wolf, R., Pieber, S.M., Bruns, e.a., crippa, m., ciarelli, g., piazzalunga, a., schwikowski, M., Abbaszade, G., Schnelle-Kreis, J., Zimmermann, R., An, Z., Szidat, S., Baltensperger, U., El Haddad, I. and
Prevot, A.S. (2014). High secondary aerosol contribution to particulate pollution during haze events in China. Nature 514: 218-222.

Jiang, Q., Sun, Y.L., Wang, Z. and Yin, Y. (2015). Aerosol composition and sources during the Chinese Spring Festival: fireworks, secondary aerosol, and holiday effects. Atmos. Chem. Phys. 15: 6023-6034.

Jung, J., Lee, D., Jeong, H., Lee, S. and Oh, S. (2018). Chemical characterization of the long-range transport of firework/firecracker emissions over the Korean Peninsula: A novel indicator of Asian continental outflows. Atmos. Environ. 178: 223-230.

Kanakidou, M., Seinfeld, J.H., Pandis, S.N., Barnes, I., Dentener, F.J., Facchini, M.C., Dingenen, R.V., Ervens, B., Nenes, A. and Nielsen, C.J. (2004). Organic aerosol and global climate modelling: A review. Atmos. Chem. Phys. 4: 1053-1123.

Kong, S., Li, X., Li, L., Yan, Y., Chen, K., Liang, Y., Zhang, Y., Shan, Y. and Ji, Y. (2015a). Variation of polycyclic aromatic hydrocarbons in atmospheric $\mathrm{PM}_{2.5}$ during winter haze period around 2014 Chinese Spring Festival at Nanjing: Insights of source changes, air mass direction and firework particle injection. Sci. Total Environ. 520: 59-72.

Kong, S.F., Li, L., Li, X.X., Yin, Y., Chen, K., Liu, D.T., Yuan, L., Zhang, Y.J., Shan, Y.P. and Ji, Y.Q. (2015b). The impacts of firework burning at the Chinese Spring Festival on air quality: Insights of tracers, source evolution and aging processes. Atmos. Chem. Phys. 15: 2167-2184.

Kroll, J.H. and Seinfeld, J.H. (2008). Chemistry of secondary organic aerosol: Formation and evolution of lowvolatility organics in the atmosphere. Atmos. Environ. 42: 3593-3624.

Larsen, R. and Baker, J. (2003). Source apportionment of polycyclic aromatic hydrocarbons in the urban atmosphere: A comparison of three methods. Environ. Sci. Technol. 37: 1873-1881.

Li, J., Zhang, G., Li, X.D., Qi, S.H., Liu, G.Q. and Peng, X.Z. (2006). Source seasonality of polycyclic aromatic hydrocarbons (PAHs) in a subtropical city, Guangzhou, South China. Sci. Total Environ. 355: 145-155.

Li, J., Wang, G., Zhou, B., Cheng, C., Cao, J., Shen, Z. and An, Z. (2012). Airborne particulate organics at the summit (2060 m, a.s.1.) of Mt. Hua in central China during winter: Implications for biofuel and coal combustion. Atmos. Res. 106: 108-119.

Li, J., Wang, G., Wang, X., Cao, J., Sun, T., Cheng, C., Meng, J., Hu, T. and Liu, S. (2013a). Abundance, composition and source of atmospheric $\mathrm{PM}_{2.5}$ at a remote site in the Tibetan Plateau, China. Tellus B 65: 20281.

Li, J., Wang, G., Aggarwal, S.G., Huang, Y., Ren, Y., Zhou, B., Singh, K., Gupta, P.K., Cao, J. and Zhang, R. (2014). Comparison of abundances, compositions and sources of elements, inorganic ions and organic compounds in atmospheric aerosols from Xi'an and New Delhi, two megacities in China and India. Sci. Total Environ. 476477: 485-495.

Li, M. and Zhang, L. (2014). Haze in China: current and 
future challenges. Environ. Pollut. 189: 85-86.

Li, W., Shi, Z., Chao, Y., Yang, L., Dong, C. and Wang, W. (2013b). Individual metal-bearing particles in a regional haze caused by firecracker and firework emissions. Sci. Total Environ. 443: 464-469.

Li, X., Guo, X., Liu, X., Liu, C., Zhang, S. and Wang, Y. (2009). Distribution and sources of solvent extractable organic compounds in $\mathrm{PM}_{2.5}$ during 2007 Chinese Spring Festival in Beijing. J. Environ. Sci. 21: 142-149.

Li, Y., Cao, J., Li, J., Zhou, J., Xu, H., Zhang, R. and Ouyang, Z. (2013c). Molecular distribution and seasonal variation of hydrocarbons in $\mathrm{PM}_{2.5}$ from Beijing during 2006. Particuology 11: 78-85.

Li, Y., Wang, W., Yang, L., Chen, X., Gao, Y., Jiang, P., Zhang, J. and Yu, H. (2017). $\mathrm{PM}_{2.5}$-bound PAHs in indoor and outdoor of hotels in urban and suburban of Jinan, China: Concentrations, sources, and health risk impacts. Aerosol Air Qual. Res. 17: 2463-2473.

Liang, L., Engling, G., Du, Z., Cheng, Y., Duan, F., Liu, X. and $\mathrm{He}, \mathrm{K}$. (2016). Seasonal variations and source estimation of saccharides in atmospheric particulate matter in Beijing, China. Chemosphere 150: 365-377.

Lin, Y., Ma, Y., Qiu, X., Li, R., Fang, Y., Wang, J., Zhu, Y. and $\mathrm{Hu}, \mathrm{D}$. (2015). Sources, transformation, and health implications of PAHs and their nitrated, hydroxylated, and oxygenated derivatives in $\mathrm{PM}_{2.5}$ in Beijing. $J$. Geophys. Res. 120: 7219-7228.

Liu, X., Li, C., Tu, H., Wu, Y., Ying, C., Huang, Q., Wu, S., Xie, Q., Yuan, Z. and Lu, Y. (2016). Analysis of the effect of meteorological factors on $\mathrm{PM}_{2.5}$-associated pahs during autumn-winter in urban Nanchang. Aerosol Air Qual. Res. 16: 3222-3229.

Medeiros, P.M., Conte, M.H., Weber, J.C. and Simoneit, B.R.T. (2006). Sugars as source indicators of biogenic organic carbon in aerosols collected above the Howland Experimental Forest, Maine. Atmos. Environ. 40: 16941705.

Medeiros, P.M. and Simoneit, B.R.T. (2008). Source profiles of organic compounds emitted upon combustion of green vegetation from temperate climate forests. Environ. Sci. Technol. 42: 8310-8316.

Meng, J., Wang, G., Hou, Z., Liu, X., Wei, B., Wu, C., Cao, C., Wang, J., Li, J., Cao, J., Zhang, E., Dong, J. and Liu, J. (2018). Molecular distribution and stable carbon isotopic compositions of dicarboxylic acids and related SOA from biogenic sources in the summertime atmosphere of Mt. Tai in the North China Plain. Atmos. Chem. Phys. 18: 15069-15086.

Mochida, M., Kawamura, K., Umemoto, N., Kobayashi, M., Matsunaga, S., Lim, H.J., Turpin, B.J., Bates, T.S. and Simoneit, B.R.T. (2003). Spatial distributions of oxygenated organic compounds (dicarboxylic acids, fatty acids, and levoglucosan) in marine aerosols over the western Pacific and off the coast of East Asia: Continental outflow of organic aerosols during the ACE-Asia campaign. $J$. Geophys. Res.. 108: 6-1-6-12.

Mochida, M., Kawamura, K., Fu, P. and Takemura, T. (2010). Seasonal variation of levoglucosan in aerosols over the western North Pacific and its assessment as a biomass-burning tracer. Atmos. Environ. 44: 3511-3518. Nirmalkar, J., Deb, M.K., Deshmukh, D.K., Tsai, Y.I. and Verma, S.K. (2015a). Molecular markers in ambient aerosol in the Mahanadi Riverside Basin of eastern central India during winter. Environ. Sci. Pollut. Res. Int. 22: 1220-1231.

Nirmalkar, J., Deshmukh, D.K., Deb, M.K., Tsai, Y.I. and Sopajaree, K. (2015b). Mass loading and episodic variation of molecular markers in $\mathrm{PM}_{2.5}$ aerosols over a rural area in eastern central India. Atmos. Environ. 117: 41-50.

Oros, D.R., Abas, M.R.b., Omar, N.Y.M.J., Rahman, N.A. and Simoneit, B.R.T. (2006). Identification and emission factors of molecular tracers in organic aerosols from biomass burning: Part 3. Grasses. Appl. Geochem. 21: 919-940.

Pongpiachan, S. (2016). Incremental lifetime cancer risk of $\mathrm{PM}_{2.5}$ bound polycyclic aromatic hydrocarbons (PAHs) before and after the wildland fire episode. Aerosol Air Qual. Res. 16: 2907-2919.

Ren, Y., Wang, G., Wu, C., Wang, J., Li, J., Zhang, L., Han, Y., Liu, L., Cao, C., Cao, J., He, Q. and Liu, X. (2017a). Changes in concentration, composition and source contribution of atmospheric organic aerosols by shifting coal to natural gas in Urumqi. Atmos. Environ. 148: 306315.

Ren, Y., Zhou, B., Tao, J., Cao, J., Zhang, Z., Wu, C., Wang, J., Li, J., Zhang, L. and Han, Y. (2017b). Composition and size distribution of airborne particulate PAHs and oxygenated PAHs in two Chinese megacities. Atmos. Res. 183: 322-330.

Ren, Y., Wang, G., Li, J., Wu, C., Cao, C., Wang, J., Zhang, L., Meng, F. and Li, H. (2018). Seasonal variation and size distribution of biogenic secondary organic aerosols at urban and continental background sites of China. $J$. Environ. Sci. 71: 32-44.

Rogge, W.F., Hildemann, L.M. and Mazurek, M.A. (1993a). Sources of fine organic aerosol. 4. Particulate abrasion products from leaf surfaces of urban plants. Environ. Sci. Technol. 27: 2700-2711.

Rogge, W.F., Hildemann, L.M., Mazurek, M.A., Cass, G.R. and Simoneit, B.R.T. (1993b). Sources of fine organic aerosol. 2. Noncatalyst and catalyst-equipped automobiles and heavy-duty diesel trucks. Environ. Sci. Technol. 27: 636-651.

Simoneit, B.R.T. (1984a). Application of molecular marker analysis to reconcile sources of carbonaceous particulates in tropospheric aerosols. Sci. Total Environ. 36: 61-72.

Simoneit, B.R.T. (1984b). Organic matter of the troposphere. III. Characterization and sources of petroleum and pyrogenic residues in aerosols over the western United State. Atmos. Environ. 18: 51-67.

Simoneit, B.R.T. (1986). Characterization of organic constituents in aerosols in relation to their origin and transport: A review. Int. J. Environ. Anal. Chem. 23: 207237.

Simoneit, B.R.T., Sheng, G. and Chen, X. (1991). Molecular marker study of extractable organic matter in aerosols from urban areas of China. Atmos. Environ. 25: 
2111-2129.

Simoneit, B.R.T. (2002). Biomass burning - A review of organic tracers for smoke from incomplete combustion. Appl. Geochem. 17: 129-162.

Simoneit, B.R.T., Elias, V.O. and Kawamura, K. (2004a). Sugars-dominant water-soluble organic compounds in soils and characterization as tracers in atmospheric particulate matter. Environ. Sci. Technol. 32: 5939-5949.

Simoneit, B.R.T., Kobayashi, M., Mochida, M., Kawamura, K., Lee, M., Lim, H.J., Turpin, B.J. and Komazaki, Y. (2004b). Composition and major sources of organic compounds of aerosol particulate matter sampled during the ACE-Asia campaign. J. Geophys. Res. 109: D19S10.

Singh, D.K., Kawamura, K., Yanase, A. and Barrie, L.A. (2017). Distributions of polycyclic aromatic hydrocarbons, aromatic ketones, carboxylic acids, and trace metals in arctic aerosols:long-range atmospheric transport,photochemical degradation/production at polar sunrise. Environ. Sci. Technol. 51: 8992-9004.

Sitaras, I.E., Bakeas, E.B. and Siskos, P.A. (2004). Gas/particle partitioning of seven volatile polycyclic aromatic hydrocarbons in a heavy traffic urban area. Sci. Total Environ. 327: 249-264.

Sorooshian, A., Ng, N.L., Chan, A.W.H., Feingold, G., Flagan, R.C. and Seinfeld, J.H. (2007). Particulate organic acids and overall water-soluble aerosol composition measurements from the 2006 Gulf of Mexico Atmospheric Composition and Climate Study (GoMACCS). J. Geophys. Res. 112: D13201.

Verma, N., Satsangi, A., Lakhani, A. and Kumari, K.M. (2017). Low molecular weight monocarboxylic acids in $\mathrm{PM}_{2.5}$ and $\mathrm{PM}_{10}$ : Quantification, seasonal variation and source apportionment. Aerosol Air Qual. Res. 17: 485498.

Wan, E.C. and Yu, J.Z. (2007). Analysis of sugars and sugar polyols in atmospheric aerosols by chloride attachment in liquid chromatography/negative ion electrospray mass spectrometry. Environ. Sci. Technol. 41: 2459-2466.

Wang, G. and Kawamura, K. (2005). Molecular characteristics of urban organic aerosols from Nanjing: A case study of a mega-city in China. Environ. Sci. Technol. 39: 74307438.

Wang, G., Kawamura, Kimitaka, Lee, S., Ho, K. and Cao, J. (2006). Molecular, seasonal, and spatial distributions of organic aerosols from fourteen Chinese cities. Environ. Sci. Technol. 40: 4619-4625.

Wang, G., Kawamura, K., Zhao, X., Li, Q., Dai, Z. and Niu, H. (2007a). Identification, abundance and seasonal variation of anthropogenic organic aerosols from a megacity in China. Atmos. Environ. 41: 407-416.

Wang, G., Zhang, R., Gomez, M.E., Yang, L., Zamora, M.L., Hu, M., Lin, Y., Peng, J., Guo, S. and Meng, J. (2016). Persistent sulfate formation from London Fog to Chinese haze. Proc. Natl. Acad. Sci. U.S.A. 48: 1363013635.

Wang, G., Cheng, S., Lang, J., Yang, X., Wang, X., Chen, G., Liu, X. and Zhang, H. (2017). Characteristics of $\mathrm{PM}_{2.5}$ and assessing effects of emission-reduction measures in the heavy polluted city of Shijiazhuang, before, during, and after the ceremonial parade 2015. Aerosol Air Qual. Res. 17: 499-512.

Wang, G., Zhang, F., Peng, J., Duan, L., Ji, Y., MarreroOrtiz, W., Wang, J., Li, J., Wu, C., Cao, C., Wang, Y., Zheng, J., Secrest, J., Li, Y., Wang, Y., Li, H., Li, N. and Zhang, R. (2018). Particle acidity and sulfate production during severe haze events in China cannot be reliably inferred by assuming a mixture of inorganic salts. Atmos. Chem. Phys. 18: 10123-10132.

Wang, G.H., Li, J.J., Cheng, C.L., Zhou, B.H., Xie, M.J., Hu, S.Y., Meng, J.J., Sun, T., Ren, Y.Q., Cao, J.J., Liu, S.X., Zhang, T. and Zhao, Z.Z. (2012). bservation of atmospheric aerosols at Mt. Hua and Mt. Tai in central and east China during spring 2009-Part 2: Impact of dust storm on organic aerosol composition and size distribution. Atmos. Chem. Phys. 12: 4065-4080.

Wang, W., Huang, M.J., Kang, Y., Wang, H.S., Leung, A.O.W., Cheung, K.C. and Ming, H.W. (2011). Polycyclic aromatic hydrocarbons (PAHs) in urban surface dust of Guangzhou, China: Status, sources and human health risk assessment. Sci. Total Environ. 409: 4519-4527.

Wang, Y., Zhuang, G., Xu, C. and An, Z. (2007b). The air pollution caused by the burning of fireworks during the lantern festival in Beijing. Atmos. Environ. 41: 417-431.

Wang, Y., Li, P.H., Li, H.L., Liu, X.H. and Wang, W.X. (2010). PAHs distribution in precipitation at Mount Taishan: China. Identification of sources and meteorological influences. Atmos. Res. 95: 1-7.

Wu, C., Wang, G., Wang, J., Li, J., Ren, Y., Zhang, L., Cao, C., Li, J., Ge, S., Xie, Y., Wang, X. and Xue, G. (2018). Chemical characteristics of haze particles in Xi'an during Chinese Spring Festival: Impact of fireworks burning. $J$. Environ. Sci. 71: 182-190.

Wu, D., Wang, Z., Chen, J., Kong, S., Fu, X., Deng, H., Shao, G. and $\mathrm{Wu}$, G. (2014). P Polycyclic aromatic hydrocarbons (PAHs) in atmospheric $\mathrm{PM}_{2.5}$ and $\mathrm{PM}_{10}$ at a coal-based industrial city: Implication for PAH control at industrial agglomeration regions, China. Atmos. Res. 149: 217-229.

Xie, M., Wang, G., Hu, S., Han, Q., Xu, Y. and Gao, Z. (2009). Aliphatic alkanes and polycyclic aromatic hydrocarbons in atmospheric $\mathrm{PM}_{10}$ aerosols from Baoji, China: Implications for coal burning. Atmos. Res. 93: 840-848.

Yang, T.T., Hsu, C.Y., Chen, Y.C., Young, L.H., Huang, C.H. and $\mathrm{Ku}, \mathrm{C} . \mathrm{H}$. (2017a). Characteristics, sources, and health risks of atmospheric $\mathrm{PM}_{2.5}$-bound Polycyclic aromatic hydrocarbons in Hsinchu, Taiwan. Aerosol Air Qual. Res. 17: 563-573.

Yang, Z., Wu, L., Yuan, J. and Li, F. (2017b). Effect of fireworks on the air quality during the Spring Festival of 2015 in Tianjin City. China Environ. Sci. 37: 69-75.

Zhang, Y., Tao, S., Shen, H. and Ma, J. (2009). Inhalation exposure to ambient polycyclic aromatic hydrocarbons and lung cancer risk of Chinese population. Proc. Natl. Acad. Sci. U.S.A. 106: 21063-21067.

Zhang, Y., Dou, H., Chang, B., Wei, Z., Qiu, W., Liu, S., Liu, W. and Tao, S. (2010). Emission of polycyclic aromatic hydrocarbons from indoor straw burning and 
emission inventory updating in China. Ann. N. Y. Acad. Sci. 1140: 218-227.

Zhang, Y., Yang, L., Zhang, X., Li, J., Zhao, T., Gao, Y., Jiang, P., Li, Y., Chen, X. and Wang, W. (2019). Characteristics of $\mathrm{PM}_{2.5}$-bound PAHs at an urban site and a suburban site in Jinan in North China Plain. Aerosol Air Qual. Res. 19: 871-884.

Zhang, Y.L., Kawamura, K., Cao, F. and Lee, M. (2015). Stable carbon isotopic compositions of low-molecularweight dicarboxylic acids, oxocarboxylic acids, $\alpha-$ dicarbonyls, and fatty acids: Implications for atmospheric processing of organic aerosols. J. Geophys. Res. 121: 3707-3717.

Zhao, W., Kawamura, K., Yue, S., Wei, L., Ren, H., Yan, Y., Kang, M., Li, L., Ren, L., Lai, S., Li, J., Sun, Y., Wang, Z. and Fu, P. (2018). Molecular distribution and compound-specific stable carbon isotopic composition of dicarboxylic acids, oxocarboxylic acids and $\alpha$-dicarbonyls in $\mathrm{PM}_{2.5}$ from Beijing, China. Atmos. Chem. Phys. 18: 2749-2767.

Zheng, M. and Fang, M. (2000). Particle-associated polycyclic aromatic hydrocarbons in urban air of Hong Kong. Water Air Soil Pollut. 117: 175-189.

Zhu, Y., Yang, L., Meng, C., Yuan, Q., Yan, C., Dong, C., Sui, X., Yao, L., Yang, F., Lu, Y. and Wang, W. (2015). Indoor/outdoor relationships and diurnal/nocturnal variations in water-soluble ion and $\mathrm{PAH}$ concentrations in the atmospheric $\mathrm{PM}_{2.5}$ of a business office area in Jinan, a heavily polluted city in China. Atmos. Res. 153: 276-285.

Received for review, August 30, 2019 Revised, September 24, 2019 Accepted, September 25, 2019 